\title{
The influence of size, age and growth on innovation management in small firms
}

\author{
Tim Mazzarol* \\ UWA Business School, \\ University of Western Australia, \\ 35 Stirling Highway, \\ Crawley WA 6020, Australia \\ Fax: +618 6488-1072 \\ E-mail: tim.mazzarol@uwa.edu.au \\ *Corresponding author
}

\section{Sophie Reboud}

Burgundy School of Business,

Group ESC Dijon Bourgogne,

29 rue Sambin BP 5060821006 Dijon, France

Fax: +333 8072-5999

E-mail: sophie.reboud@escdijon.eu

\section{Thierry Volery}

Swiss Research Institute of Small Business and Entrepreneurship,

University of St. Gallen.,

Dufourstrasse 40a,

9000 St Gallen, Switzerland

Fax: +41 71-224-7101

E-mail: thierry.volery@unisg.ch

\begin{abstract}
This study examines the innovation management practices of small firms in Australia, France and Switzerland. The focus was on how firm size, age and growth influence the commercialisation process. A sample of 143 firms was surveyed across the three countries. Findings from the study suggest that the size of the firm, its age and pace of growth are important determinants in influencing how firms behave. Consistent with the findings from earlier studies the need for greater formalisation and external assistance as firms grow, and the need for customer research and independent testing when innovations are in their early stages were found.
\end{abstract}

Keywords: innovation management; small firms; commercialisation.

Reference to this paper should be made as follows: Mazzarol, T., Reboud, S. and Volery, T. (2010) 'The influence of size, age and growth on innovation management in small firms', Int. J. Technology Management, Vol. 52, Nos. 1/2, pp. $98-117$. 
Biographical notes: Tim Mazzarol is a Professor of Entrepreneurship and Strategy at the UWA Business School at the University of Western Australia. $\mathrm{He}$ was formerly the Director of the UWA Centre for Entrepreneurial Management and Innovation (CEMI). He has 15 years experience of working with small entrepreneurial firms as well as large corporations and government agencies. This has included strategic management, marketing and support to commercialisation. His research into small business management has been published internationally. He holds a PhD in Management and an MBA with distinction from Curtin University of Technology, and a Bachelor of Arts with Honours from Murdoch University, Western Australia.

Sophie Reboud is the Head of Research and a Professor of Strategy and Management of Innovation at the Burgundy School of Business, Group ESC Dijon-Bourgogne, France. She has ten years of experience as a Researcher and Consultant in the field of management and strategy. Originally trained as an Agronomist, she served as a Research Engineer for École Nationale Supérieure des Mines de Paris for five years, and completed her PhD there. Her research interests are in the strategic management of innovation and technology. This includes firms in the biotechnologies and new technologies with specific focus on intellectual property and strategy in small firms.

Thierry Volery is a Professor of Entrepreneurship and Director of the Swiss Institute for Entrepreneurship and Small Business at the University of St. Gallen, Switzerland. He holds a Doctorate in Business Economics and Social Sciences from the University of Fribourg, Switzerland. Thierry is the co-author of 'Entrepreneurship and Small Business Management: A Pacific Rim Perspective' (John Wiley \& Sons, 2007).

\section{Introduction}

This paper examines the behaviour of small innovator firms from three countries; Australia, France and Switzerland. Four primary research questions were addressed:

1 What impact does size of firm have upon the innovation behaviour of small firms?

2 What impact does the age or maturity of the firm have upon its innovation management?

3 What is the relationship between the firm's management of innovation and its rate of growth?

4 Are there any differences between the innovation management practices of firms from the three countries and what might explain such differences?

The study is exploratory in nature and provides preliminary evidence of innovation management practice in small firms across three countries: Australia, Switzerland and France. The authors are engaged in a larger research project involving data collection from 11 of the 30 countries within the organisation for economic cooperation and development (OECD) that is investigating innovation management in small firms. The initial data from these first three countries is therefore presented here. For the purposes of 
the study, small firms were defined as those with fewer than 500 employees in order to accommodate size differences in the definition of small to medium enterprises across the three countries. While each country has many differences they are also very similar as advanced western economies.

\section{Managing innovation in small firms}

Although the popular image suggests that small firms are exemplars of entrepreneurship and innovation, this perception needs to be tempered by the recognition that most small businesses lack a clear point of market differentiation and their continuous change in pursuit of new market opportunities ensures that they will appear highly innovative (Gibb, 2000). Upon closer scrutiny, the level of innovation within small firms may vary significantly depending on the strategic aims and capacity of their leadership. Just as Miles and Snow (1978) found large firms can be grouped into different strategic types displaying more or less innovation and opportunism, so to have other studies found similar strategic behaviour among small firms (Khan and Manopichetwattana, 1989). Just as large firms can range from highly entrepreneurial innovative 'prospectors' to non innovative 'reactors' (Miles et al., 1978), so might small firms range from highly innovative entrepreneurial types to more reactive and conservative organisations (Vazquez et al., 2001; Kickul and Gundry, 2002). The entrepreneurial manager's ability to make sense of their environment and the role they should play is likely to determine what strategy they follow (Coopey et al., 1997).

\subsection{The commercialisation process}

Assuming that the small firm is seeking to commercialise a new technology or use innovation as a key driver in their business, there will be a need for the management team to adopt a systematic process (Grupp and Maital, 2001). A strategic approach to innovation management, new product development and the commercialisation process is required (Stringer, 2000). The formation of a close partnering with leading customers and key suppliers in order to ensure a transfer of ideas to assist the development of the new product is also critical (Miller, 2001). For many small innovator firms that have a strong technology base, the major point of focus is upon the R\&D and technical development of the product itself. However, success in new product development (NPD) within small firms is likely to depend equally upon their capacity to understand the market and to obtain formal assessments of the market and its acceptance of their new product (Huang et al., 2002). This is particularly important where the innovation is radical or highly disruptive of a target market (Sandberg, 2002). The challenge of NPD is significant for both manufacturers and service firms, with most small firms suffering from a lack of resources and managerial expertise to undertake the commercialisation process (Vermeulen, 2005).

Whatever the size of the firm, NPD requires a systematic, holistic, flexible and continuous process that engages all the firm's employees and promotes a sharing of ideas and knowledge (Ozer, 2004). Successful NPD requires firms to have a culture supportive of innovation, senior managers that are committed to the process, and project teams that are organised, resourced and rewarded appropriately (Cooper et al., 2004a). In managing NPD, best practice requires managers to undertake a portfolio approach continuously 
reviewing their best and worse case options, and matching often limited resources to emerging opportunities (Cooper et al., 2004b). Successful NPD depends on the firm's ability to match the customer's needs and offer superior benefits or better value for money (Cooper et al., 2004c). Finally, the NPD process takes place within a wider context of innovation management for which there are at least seven distinct elements:

1 inputs, such as human creativity, ideas and resources (both physical and financial)

2 knowledge management

3 strategy, both the NPD strategy and the overall business strategy

4 organisation and culture

5 portfolio management

6 project team management

7 commercialisation, which involves taking the product to market either directly or via joint ventures and alliances (Adams et al., 2006).

It is not a linear process but one that requires senior management to be flexible and adaptable within dynamic technological and market environments. Small entrepreneurial firms where the senior managers also have equity and personal finances tied up in the venture are more likely to focus on success within the commercialisation process (Mattes et al., 2006).

\subsection{The effects of size, age and firm maturity}

Innovation within small firms can involve the development of new products or services, the development of new markets or marketing methods, new process technologies within operations, or the application of technology or innovation to administrative systems (North and Smallbone, 2000). As a firm grows in size and complexity, and becomes established in its markets, the nature of its innovation focus is likely to change. Therefore, the extent and nature of innovation practice within firms appears to be influenced partially by such demographic variables as size, age and level of firm maturity. For example, a national study of innovation among Australian firms found large firms (e.g. with over 200 employees) had double the rate of innovation activity than smaller firms, and the type of innovation undertaken also changed. Large and small firms were focused mainly on operational process innovations, while mid-sized firms (e.g. with 20 to 200 employees) were mainly focused on administrative innovations (ABS, 2005).

Autio and Lumme (1998) segmented small innovator firms into four types: application, market, technology and paradigm innovators. The first simply apply existing technology to an existing market and are not particularly innovation intensive, their innovations are more market development in nature. The market innovators are good at combining existing technologies to form new product combinations and sell these into new markets. The technology innovators introduce new technologies into existing markets and frequently challenge the status quo with new products. Finally, the paradigm innovators are specialists in creating fundamental new technologies that involve radical shifts in the status quo and a deep R\&D base. Differences in innovative behaviour and intensity appeared to be related to size and growth. The growth rate of the paradigm 
innovators was likely to be faster than the others, but such firms are typically the smallest and faced the most significant challenges. The largest firms were the application innovators (Autio and Lumme, 1998). There seems to be an association between innovation intensity within the firm and the overall success of the business in terms of sales and productivity (Klomp and van Leeuween, 1999); the nature of the innovation and how it is managed can influence the firm's overall growth rate and performance (Kemp et al., 2003).

\section{Innovation in Australia, France and Switzerland}

The selection of Australia, France and Switzerland within this study was opportunistic. As noted above, the authors are engaged in a larger study of innovation within small firms across the OECD group of countries. At first glance each country appears to be very different. For example, Australia is in the Asia-Pacific and is a resource rich economy close to Asia. France is a member of the EU and has an economy with both a large manufacturing base and a significant agricultural sector. Switzerland is a small non-EU nation, but one that is closely integrated into the wider European economy and a major centre for financial services. Despite such differences, an examination of the three countries using OECD statistics suggests a high degree of similarity.

As shown in Table 1, while France has a much larger population and overall economy than Australia and Switzerland, many of the other key statistics are similar. Per capita income levels are similar as is the proportion of small firms within the manufacturing sector. Worker productivity, investment in R\&D and ICT, internet connectivity per household and investments in education are also relatively similar. Each country also has a national government that is concerned with both national productivity and enhanced innovation. For Australia, this has been in the agriculture sector (Marsh and Pannell, 2000) as well as industry more broadly (Roach, 2000; Ferris, 2001; Kerin, 2006). Innovation that leads to commercialisation has been viewed as an important area of policy focus (Wood, 1992; Molyneux, 2000; DCITA, 2004; Garrett-Jones, 2004; Yencken and Gillin, 2006). This focus on innovation since the early 1990s has enabled Australia to rank well against other OECD nations (ABS, 2005).

France has also focused on enhancing innovation (MEFE, 2006), with a specific focus on small firms (MEDEF, 2002; OSEO, 2006). This has also included major investment into the national innovation system targeted at fostering R\&D, business start-up, industry clustering and the development of regional economies (SESSI, 2006; OSEO, 2006). In terms of patents lodged within the 'triadic patent family' network of Europe, North America and Japan (Dernis and Khan, 2004), France and Switzerland have substantially more patent families than Australia. However, the growth rate in Australian patenting activity over the period 1990 to 2003 has been impressive (OECD, 2007).

In summary, these three countries are diverse in terms of location, size and population density, but very similar in terms of their national innovation environment. A comparison of small firms across these three countries should suggest that environmental impacts are negligible, but we were also interested in any differences. 
Table 1 General data on Australia, France and Switzerland (2005)

\begin{tabular}{|c|c|c|c|}
\hline Country & Australia & France & Switzerland \\
\hline Total population (millions) & $20.3 \mathrm{~m}$ & $60.9 \mathrm{~m}$ & $7.4 \mathrm{~m}$ \\
\hline GDP (US \$ billions) & $\$ 701$ bn & $\$ 1,897$ bn & $\$ 267.4$ bn \\
\hline Real GDP growth rate & $2.8 \%$ & $1.2 \%$ & $1.9 \%$ \\
\hline Per capita GDP (US \$) & $\$ 34,239$ & $\$ 30,266$ & $\$ 35,649$ \\
\hline $\begin{array}{l}\text { Proportion of manufacturers that are small } \\
\text { firms }\end{array}$ & $94 \%$ & $90 \%$ & $88 \%$ \\
\hline Unemployment rate & $5 \%$ & $10 \%$ & $4.5 \%$ \\
\hline Self-employment rate & $13 \%$ & $9 \%$ & $11 \%$ \\
\hline $\begin{array}{l}\text { Average hours worked during the year per } \\
\text { person }\end{array}$ & 1,730 & 1,546 & 1,658 \\
\hline GDP expenditure on $R \& D$ per annum & $1.64 \%$ & $2.16 \%$ & $2.94 \%$ \\
\hline $\begin{array}{l}\text { Number of persons employed in R\&D per } \\
\text { thousand }\end{array}$ & 7.83 & 7.75 & 6.08 \\
\hline $\begin{array}{l}\text { Investment in ICT as a } \% \text { of total } \\
\text { non-residential fixed capital formation }\end{array}$ & $21.5 \%$ & $16.4 \%$ & $\mathrm{n} / \mathrm{a}$ \\
\hline $\begin{array}{l}\text { Proportion of households with access to home } \\
\text { computers }\end{array}$ & $67 \%$ & $50 \%$ & $71 \%$ \\
\hline $\begin{array}{l}\text { Proportion of households with access to the } \\
\text { internet }\end{array}$ & $56 \%$ & $34 \%$ & $73.5 \%$ \\
\hline $\begin{array}{l}\text { Proportion of age group } 25 \text { to } 64 \text { years with } \\
\text { tertiary level education }\end{array}$ & $31 \%$ & $24 \%$ & $28 \%$ \\
\hline $\begin{array}{l}\text { Expenditure per student in tertiary education: } \\
2003 \text { constant prices (US \$) }\end{array}$ & $\$ 12,405$ & $\$ 10,704$ & $\$ 25,900$ \\
\hline $\begin{array}{l}\text { Total expenditure as \% of GDP on education } \\
\text { institutions for all levels of education }\end{array}$ & $5.8 \%$ & $6.3 \%$ & $6.5 \%$ \\
\hline
\end{tabular}

Source: OECD statistics, http:///stats.oecd.org

\section{Methodology}

This study examined the innovation management practices of 143 small firms. A survey was developed that examined the innovation activity of these firms, including their formal commercialisation and NPD practices. The approach taken was to interview the managers from each firm face-to-face using a computer based questionnaire that allowed the researchers to explain the question items and seek respondent feedback to particular items. Transcripts of the interview were also captured in most cases for subsequent qualitative analysis. Such mixed methodology approaches are recognised as offering an effective and pragmatic means of investigating strategic management issues (Molina-Azorin, 2007). In this paper, we report only part of the quantitative findings of the study. 


\subsection{Sampling}

Selection of the firms for the sample was undertaken on the basis of size and level of innovation. The OECD (2004) definition of small firms and innovation (OECD, 2001) was used to define the parameters for firm selection, although cases with up to 500 employees were permitted into the study. As there were no reliable databases of innovative small firms, the research team, in order to boost the size of the final sample, made use of some held by government agencies, listings in technology parks, and their personal networks within the business communities of their home countries. The initial aim of the data collection in terms of number of firms was 60 to 70 interviews; however the response rates differed within each country resulting in 64 Australian, 40 Swiss and 39 French firms.

The respondents comprising the sample were predominately male (92\%) of whom the majority $(69 \%)$ were under the age of 50 years. Chi-square tests found no significant differences between the countries in terms of gender, but significant differences were found in terms of age. French firms had significantly more respondents aged below 30 years as well as significantly more who were aged over 50 years. In terms of ownership structure, Swiss firms had significantly more respondents who described themselves as executive managers with shareholding $(48.5 \%)$ or without shareholding $(30 \%)$, as compared to Australian firms where the respondent was more likely to be an owner-manager $(37.5 \%)$ or an executive manager who was the principal shareholder $(20 \%)$; or the French firms, where there was a more even spread of managerial ownership structures.

Table 2 A comparison of Australian and French case study firms

\begin{tabular}{|c|c|c|c|}
\hline Characteristics & Australia & France & Switzerland \\
\hline Average age of the firm & 12 years & 39 years & 29 years \\
\hline Average number of full time employees & 33 & 95 & 68 \\
\hline $\begin{array}{l}\text { Average number of full time employees three } \\
\text { years previously }\end{array}$ & 24 & 86 & 57 \\
\hline Average gross annual turnover (millions US) & \$US $6.7 \mathrm{~m}$ & \$US $26.4 \mathrm{~m}$ & \$US $25.3 \mathrm{~m}$ \\
\hline $\begin{array}{l}\text { Average gross annual turnover three years } \\
\text { previously (millions US) }\end{array}$ & \$US $3.6 \mathrm{~m}$ & \$US $23.2 \mathrm{~m}$ & \$US $18.5 \mathrm{~m}$ \\
\hline $\begin{array}{l}\text { Average investment in innovation as a } \% \text { of } \\
\text { annual turnover over previous three years }\end{array}$ & $30.4 \%$ & $5.4 \%$ & $17.5 \%$ \\
\hline $\begin{array}{l}\text { Proportion of firms planning a technological } \\
\text { product innovation }\end{array}$ & $84.4 \%$ & $59.0 \%$ & $87.2 \%$ \\
\hline $\begin{array}{l}\text { Proportion of firms planning a technological } \\
\text { process innovation }\end{array}$ & $59.4 \%$ & $64.1 \%$ & $38.5 \%$ \\
\hline
\end{tabular}

The sample firms were drawn from a variety of industries, although the largest proportion (31\%) was manufacturers, which is explained by the desire to find firms that had clearly identifiable innovations. No significant differences were found between the three countries in terms of industry type. The firms comprised both start up ventures with less than one year in operation, to one firm that had been in operation for 134 years. The average length of time the firms had been in operation was 24 years. ANOVA tests found that Australian firms were on average younger than those from France and Switzerland. Table 2 provides a descriptive comparison of the three country sub-samples. It can be 
seen that innovation intensity (as measured by investment in new product or process technologies) was high.

\subsection{Development of the survey instrument}

The questionnaire used in the study was developed as a diagnostic tool designed to assist managers from small firms to evaluate the risk and return of future investment in a particular innovation, and to assess their managerial practices in relation to commercialisation, considered as critical points for a small firm, as mentioned in the introduction of the paper. It includes also a set of questions on the perception of the national environment. It builds upon work originally commenced by Santi et al. (2003), Mazzarol and Reboud (2005, 2006) and Reboud and Mazzarol (2006) that examined the strategic decision making of entrepreneurs in small firms seeking to commercialise a new innovation.

Commercialisation management was measured in the survey using a scale initially developed by Mazzarol and Reboud (2006) that consists of 40 items arranged into four distinct indices relating to market, innovation, resources and strategy. Each of the four indices has ten items and scale reliability testing on these items found good alpha scores (Cronbach, 1951), ranging from resources (alpha $=0.627$ ), through innovation $($ alpha $=0.700)$ and strategy $($ alpha $=0.767)$, to market $($ alpha $=0.799)$. These items are listed in Appendix A.

\subsection{Discriminant analysis}

The survey data was subsequently examined using a discriminant analysis procedure, which is a useful technique for building predictive models of group membership based on the characteristics of individual cases. The group memberships used for this analysis were size, age and growth rate. Size was measured by the number of full time employees that the firm had at time of interview. The sample was divided into three equal groups: micro firms (e.g. with < 11 employees); small firms (e.g. 11 to 56 employees); and medium firms (e.g. $>56$ employees).

Age was similarly derived from the number of years the firm had been established. Once again, three equal groups were created with: young firms (e.g. $<7$ years old); adolescent firms (e.g. 7 to 21 years old); and mature firms (e.g. $>21$ years old). Finally, growth was measured using a scale derived from the rate of growth in the firm's annual turnover as measured over a period of three years. Three equal groups were identified comprising: low growth (e.g. $<19 \%$ growth in annual turnover); medium growth (e.g. $19 \%$ to $46 \%$ growth in annual turnover); and high growth (e.g. $>46 \%$ growth in annual turnover).

The discriminant analysis models were run using the step-wise procedure in the SPSS statistical software program. In each case, a varimax rotation procedure was employed in order to provide clear separation of the functions. A hold out sample was not employed as the predictive accuracy of the final model was not the paramount objective of this analysis (Birley and Westhead, 1993). For each model, Wilk's Lambda statistics were used to determine if the discriminant models as a whole were significant (Wilks and Thompson, 1937). Rao's V was used to determine the inclusion of the items in the models with a range from 0.05 to 0.10 significance levels of the F-statistics determining entry or removal. The minimum Rao's V for entry was zero. In each case, the analysis 
used the 40 items measuring commercialisation and NPD practice (see Appendix A) as the independent variables, and the measures of size, age and growth as the grouping variables. The rotated standardised canonical discriminant function coefficients for the significant independent items within each model were then used in conjunction with the group centroid functions for the grouping variables to estimate visual plots illustrating the relationships between these variables. These results are described below.

\section{The effect of size, age and growth}

As was shown in Table 2, the Australian, French and Swiss firms differed from each other in relation to age, size and level of innovation intensity. However, while these findings suggest that there are differences between these three countries the answer lies more with the factors of size, age and growth rates.

\subsection{Discriminant analysis: size effects}

The sample divided into three equal groups representing micro, small and medium sized firms. The discriminant analysis used $93 \%$ of the cases in the sample, the rest were excluded due to missing discriminating variables. As shown in Table 3, five of the 40 independent variables were identified as significant within the model.

Table 3 Rotated standardised canonical discriminant function coefficients ${ }^{\mathrm{a}}-$ size

\begin{tabular}{lcc}
\hline Function & 1 & 2 \\
\hline $\begin{array}{l}\text { Have you fully researched the benefits as perceived by the customer for } \\
\text { this innovation? }\end{array}$ & -.462 & .703 \\
Do you have a formal process for new product development? & .534 & .473 \\
Are financial resources adequate for the future development of the idea? & .641 & -.266 \\
Have you identified sources of venture capital financing for the & -.572 & -.355 \\
innovation? & .361 & -.474 \\
Have you considered existing or anticipated government regulations? & .582 & .260 \\
Canonical correlation for function & .616 & .932 \\
Wilks' Lambda (1 through 2 chi-square 61.92; Sig. .000)
\end{tabular}

Notes: Coefficients are based on rotated structure matrix.

a $\%$ of variance by function $1=83.8$, function $2=16.2$.

Figure 1 illustrates the findings using a diagram to plot the relationship between the three size groupings and the independent descriptors. Each of the five items listed in Table 3 are shown as arrows with the direction representing the coefficient scores across the two functions and the length of the arrow indicating the strength of the coefficients. The three grouping variables are plotted using their unstandardised canonical discriminant functions evaluated at group means (Functions at group centroids). 
Figure 1 Plot of innovation management by size

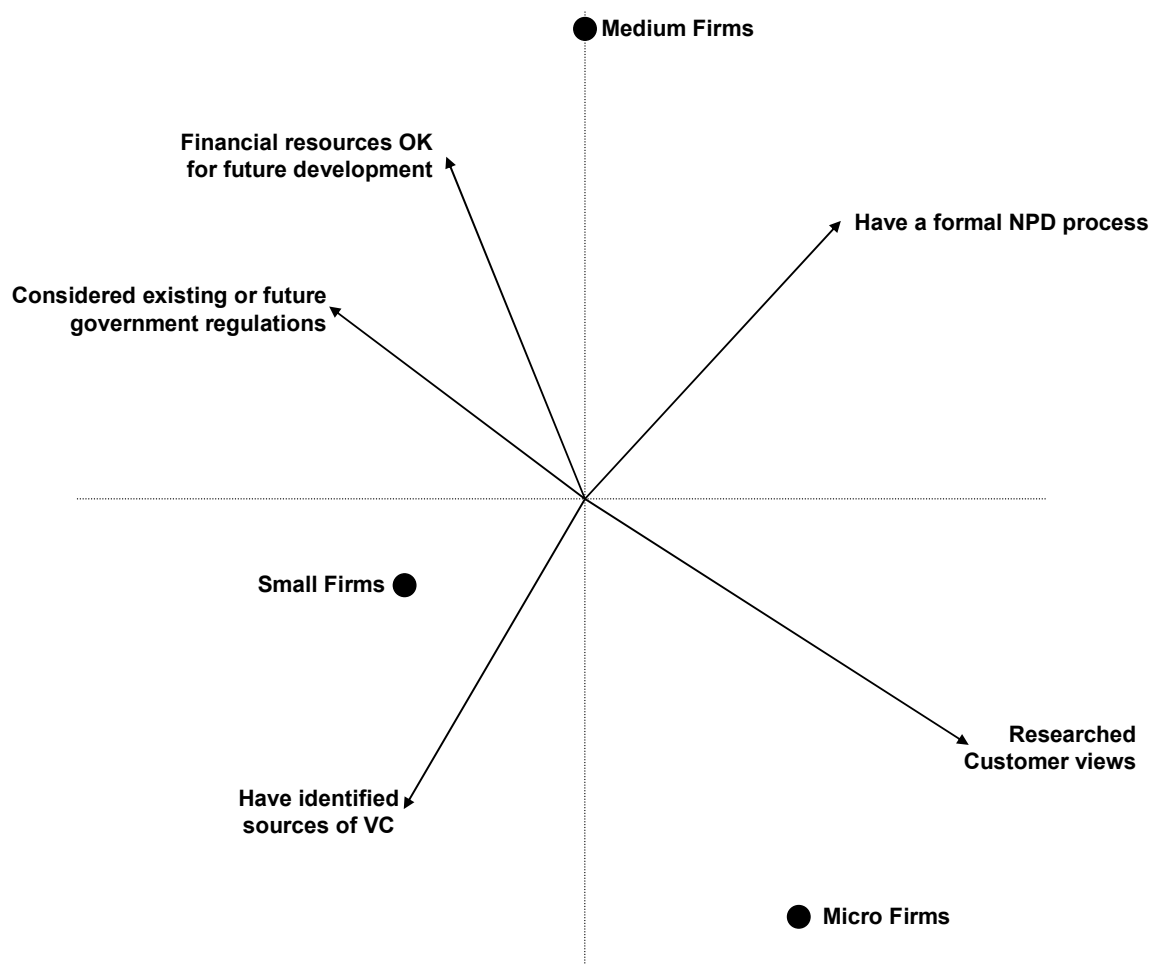

It can be seen from Figure 1 that the micro firms were characterised by stronger research of customer perceptions of the benefits of the innovation. By comparison the small firms were characterised by having identified sources of external financing such as venture capital. Finally, the medium sized firms were characterised by having formal new product development processes, stronger financial resources for the innovation's future development, and a greater consideration of existing or anticipated changes to government regulation. The model correctly classified $62.5 \%$ of the micro and $67.4 \%$ of the medium sized firms. However, only $49 \%$ of the small firms were correctly classified suggesting that the predictive power of the model for the small firms was weak in comparison to the micro and medium firms.

\subsection{Discriminant analysis: age effects}

For the age of firms, they are divided into three broadly equal groups with 46 young, 49 adolescent and 48 mature firms. The discriminant analysis used $93 \%$ of the cases in the sample, as shown in Table 4 , four of the 40 independent variables were identified as significant within the model. 
Table 4 Rotated standardised canonical discriminant function coefficients ${ }^{\mathrm{a}}$ : age

\begin{tabular}{lcc}
\hline Function & 1 & 2 \\
\hline Have you fully researched the benefits as perceived by the customer for this & .478 & .506 \\
innovation? & & \\
Do you have the competencies to fully commercialise the innovation alone? & -.846 & .389 \\
Have you identified sources of venture capital financing for the innovation? & .455 & .628 \\
Have you secured all necessary compliances and authorisations? & -.056 & -.810 \\
Canonical correlation for function & .481 & .229 \\
Wilks' Lambda (1 through 2 chi-square 40.69; Sig. .000) & .729 & .947 \\
\hline
\end{tabular}

Notes: Coefficients are based on rotated structure matrix.

${ }^{\mathrm{a}} \%$ of variance by function $1=65.2$, function $2=34.8$.

Figure 2 Plot of innovation management by age of firm

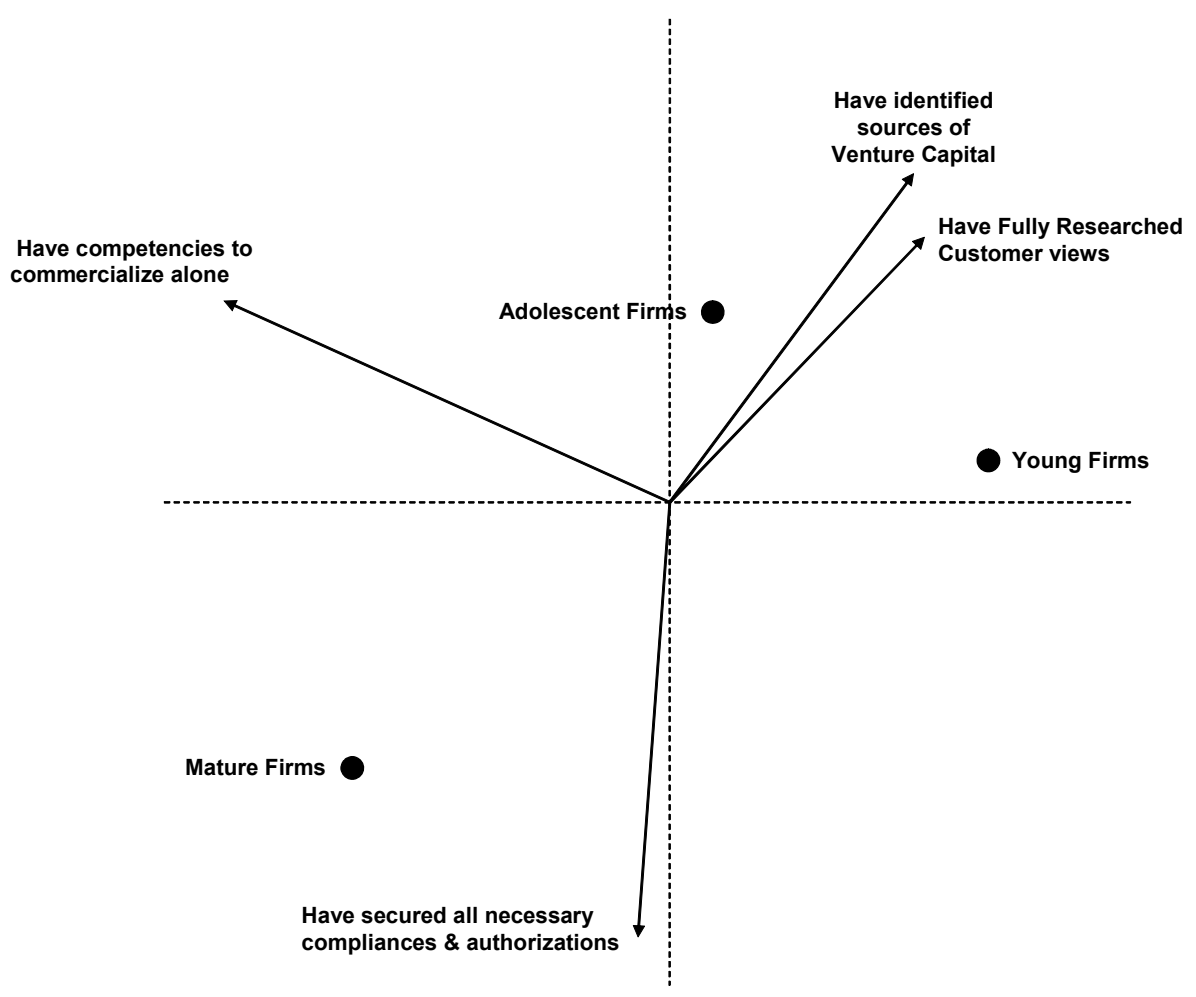

Figure 2 illustrates these findings using the same approach as for size. As can be seen, the separation between the mature firms and the other two was greatest, suggesting that young and adolescent firms are closer to each other than they are to mature firms. Mature firms were more likely to have secured all the necessary compliances and authorisations required for the commercialisation of the innovation. Their competence in undertaking the commercialisation alone was also stronger than for the young firms. Young and adolescent firms were characterised more by their focus on understanding customer 
views towards the innovation, and identifying sources of venture capital. The model correctly classified $62.5 \%$ of mature firms, but only $54 \%$ of young and $39 \%$ of adolescent firms were correctly classified. This suggests that the model was a poor predictor for the young and adolescent firms and generally not reliable.

\subsection{Discriminant analysis: growth effects}

Firm growth statistics divided the sample into three groups comprising 39 low, 65 medium and 39 high growth firms. The discriminant analysis used $93 \%$ of the cases in the sample, as shown in Table 5 two of the 40 independent variables were identified as significant within the model. However, only $51 \%$ of the high growth and $56 \%$ of the medium growth firms were correctly classified, and a mere $35 \%$ of the low growth firms. The predictive power of this model was therefore also weak.

Table 5 Rotated standardised canonical discriminant function coefficients ${ }^{\text {a }}$ : growth

\begin{tabular}{lcc}
\hline Function & 1 & 2 \\
\hline Do you have a management board to provide guidance and advice? & -.292 & .970 \\
Have you fully assessed the bargaining power of your suppliers? & 1.005 & .131 \\
Canonical correlation for function & .276 & .219 \\
Wilks' Lambda (1 through 2 chi-square 16.64; Sig. .002) & .879 & .952 \\
\hline
\end{tabular}

Notes: Coefficients are based on rotated structure matrix.

a $\%$ of variance by function $1=59.6$, function $2=40.4$.

\section{Innovation management by country}

To determine if there were any differences across the three countries, a further discriminant analysis model was run using the same 40 items as independent variables and the countries as grouping variables. Table 6 shows the results where it can be seen that nine items were found to be significant within the model. Overall, $79 \%$ of the cases were correctly classified, with $87 \%$ of the Swiss, $82 \%$ of the French and $73 \%$ of the Australian firms correctly classified. As shown in Figure 3 the Swiss firms were characterised by having management boards for outside help and advice, greater confidence in their ability to access physical resources for future development and growth, and an active involvement of customers in the development of their innovations. By contrast, the Australian firms were characterised by greater use of government support for commercialisation, strong research of the customers needs in relation to the future product or innovation being developed, and a greater emphasis on having the innovation independently tested. French firms were characterised by having greater confidence in being able to develop their innovation without outside help, and having sufficient staff resources for its future development. The variable, having prepared a comprehensive financial model of the innovation as part of the commercialisation process was more likely to be associated with the French firms than the others. 
Table 6 Rotated standardised canonical discriminant function coefficients ${ }^{\text {a }}$ : country

\begin{tabular}{lccc}
\hline Function & 1 & 2 \\
\hline $\begin{array}{l}\text { Have you fully researched the benefits as perceived by the customer for this } \\
\text { innovation? }\end{array}$ & -.059 & .979 \\
$\begin{array}{l}\text { Do you feel that you could fully develop the prototype technically without } \\
\text { outside assistance? }\end{array}$ & -.403 & -.320 \\
$\begin{array}{l}\text { Are you confident that the innovation has been independently tested or } \\
\text { evaluated? }\end{array}$ & -.431 & .083 \\
$\begin{array}{l}\text { Do you actively involve customers in developing your new innovation(s)? } \\
\text { Are staffing resources adequate for the future development of the idea? }\end{array}$ & .381 &. .127 & -.503 \\
Are physical resources adequate for the future development of the idea? & .573 & .234 \\
Have you fully explored government assistance programs designed to help & -.356 & .207 \\
small firms with commercialisation? & .717 & .059 \\
Do you have a management board to provide guidance and advice? & .018 & -.665 \\
Have you completed a comprehensive financial model & .709 & .570 \\
Canonical Correlation for Function & .336 & .675 \\
\hline Wilks' Lambda (1 through 2 chi-square 137.56; Sig. .000):
\end{tabular}

Notes: Coefficients are based on rotated structure matrix.

${ }^{\mathrm{a}} \%$ of variance by function $1=64.8$, function $2=35.2$.

Figure 3 Plot of innovation management by country

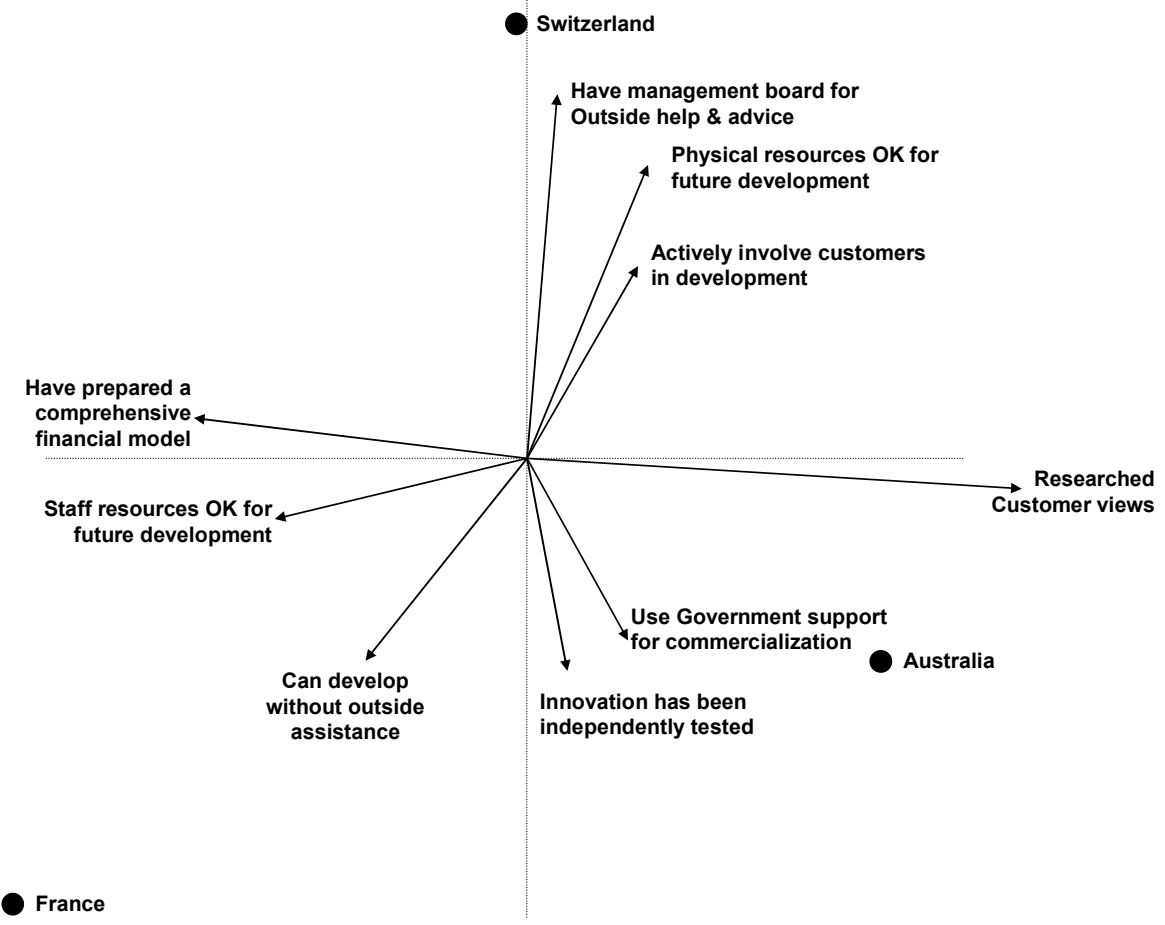




\section{Discussion of the findings}

What do these findings tell us about the nature of innovation management in small firms? Can they provide meaningful answers to the four research questions outlined at the start of this paper? With respect to the four research questions initially raised by this study, the findings suggest that while some differences appear to exist between firms in relation to size, age and growth, the more significant differences were identified in relation to country.

\subsection{The impact of size, age and growth}

The findings suggest that firm size and age may have influences on how small firms manage commercialisation of innovation. Larger firms were found to have stronger financial resources and more formalisation in their NPD processes than their small and micro counterparts. They were also found to be more likely to consider future government regulations that might impact on their innovation. By contrast the micro firms were characterised by the need to research customer needs and the small firms by a focus on identifying sources of potential venture capital. Although the predictive strength of the discriminant model used to classify the firms by size was weak for the small firms, this general pattern of relationships is logical. Larger firms would be expected to have developed more formality in their NPD processes and to have greater financial resources to fund the commercialisation activity. Micro firms, typically start ups with new and unknown innovations, would also be expected to need to undertake market research and canvass customer opinions. These findings are consistent with the best practice benchmarks in NPD found within the literature (Boag and Rinholm, 1989; Cooper et al., 2004a, 2004b, 2004c; Akgun et al., 2004).

The pattern of behaviour for firm age is similar to that found for size. The older, mature firms were found to be more confident that they possessed the competencies to commercialise the innovation alone, and to have all the necessary compliances and authorisations in place. This would be consistent with a well established NPD process and stronger resources, both financial and human. By contrast the young and adolescent firms were more likely to be focusing on understanding customer needs and to look for venture capital funding. These findings are consistent with other research into the innovation of small firms, which highlight the importance of simultaneously developing a clear understanding of the end user market needs as the technology within the new product is being developed (Pavia, 1990; Huang et al., 2002; Lee and O'Connor, 2003).

Growth was not found to be a strong discriminator within the modelling undertaken, however, the results point to the higher growth firms being more outwardly focused, either on the bargaining power of key suppliers who are likely to impact cost and quality, or in seeking the support from independent advisory boards. McDougall et al. (1994) suggest that high growth in new ventures is linked to aggressive NPD-led new market entry strategies with attention given to specialised products that can be effectively marketed into targeted segments. The NPD process is also identified as being enhanced by both good project management and risk management planning within the firm (Salomo et al., 2007). Assessment of the bargaining power of key suppliers is associated with this risk management planning process. Use of advisory boards can also help to expand and strengthen the firm's management competencies, a factor that has been associated with growth in the small firm (Weinzimmer, 1997). 
In summary, the study provides some tentative evidence of the impact of size and age on small firm innovation. Unsurprisingly, they show that larger more mature firms will be more likely to possess the resources and competence to undertake NPD and commercialisation alone. Smaller firms will, by contrast be more focused on understanding how their new product or service will be accepted by the customer, and identifying sources of additional funding to help them commercialise it.

\subsection{Differences between countries}

As demonstrated in the final discriminant model, there were some differences identified between the firms when examined by country. Australian firms were more likely to be focusing on customer perceptions of their innovations, having their innovation independently tested and seeking commercialisation assistance from the government. Swiss firms were more likely to have managerial boards for outside help and advice, and to actively involve customers in the NPD process. They were also more confident of their ability to have sufficient physical resources for the commercialisation. By contrast the French firms were confident of their staff resources and had comprehensive financial models. They were more confident of being able to develop the innovation without external support.

These differences between the three countries can be partially explained by reference to the data shown in Table 2. French firms were generally much larger than their Australian or Swiss counterparts. They were also less likely to be engaged in a technological product innovation. By contrast the Australian firms were smaller, younger and more likely to be engaged in product innovations, while Swiss firms were more likely to be mid-sized and older. While the majority of Australian and Swiss firms were engaged in technological product innovations, the French firms were more evenly divided between product and process innovations. This appears to have played a role in their responses, with them being more confident of having the ability to develop the innovation without outside help, and being less focused on understanding the market or customer needs.

While size and age may explain a lot of these differences there may also be a degree of country effect. For example, the Australian government has sought to boost its national innovation activity via a range of policies specifically targeted at small firms engaged in NPD and commercialisation (DCITA, 2004). Many of the French firms were well established, mature companies from within the Bourgogne region and were engaged in more traditional sectors of activity, with some even showing a reluctance to change traditional products. This may explain their stronger focus on process innovation. Many of the Swiss firms were from the Zurich region and were able to access the strong support base to innovation including access to venture financing and university R\&D centres.

\section{Conclusions}

The commercialisation of new product or process technologies and the general management of innovation and NPD within small firms remains a poorly researched area of inquiry. Much attention in this regard has focused on the NPD and commercialisation practices of large firms that are well supported with resources, specialist skills, experience managers and ready access to markets. For the entrepreneurial manager of a 
small firm, the lack of resources, skills and managerial support combines with their lack of ready access to markets to make the process of NPD and commercialisation particularly challenging. Despite these problems the level of NPD and commercialisation of innovations within the small firms sector remains high.

As the paper suggest, the management of innovation and the NPD process changes with the size of the firm. Micro-firms are more likely to be concerned with understanding customer views and whether their innovation will be accepted in target markets. Small firms may begin to identify potential sources of external financing while medium sized firms will be more formal in their NPD process, planning strategy, marshalling resources and systematically protecting IP rights. Small firms seeking to engage in innovation need to be willing to form strategic alliances with customers and suppliers, research centres and other firms in order to leverage the resources of other parties so as to make up for their own deficiencies.

Government policy makers seeking to assist small firms to commercialise their innovations should recognise that they need to take a dual track approach. At the macro level they need to ensure that there is access to quality research centres, skilled and educated workers, qualified managers, financing and communications infrastructure. At the micro level there is a need for focused support schemes that allow small firms to access early stage seed capital for R\&D and commercialisation. Marketing and business development support from skilled advisors should also be made available, along with mechanisms to facilitate firms to identify and contact strategic alliance partners. Assistance with marketing and access to university $R \& D$ centres for independent product testing will be of most value to micro and small firms seeking to get established. Policy responses should be tailored to the needs of micro-enterprises and small firms.

The study has some limitations. It examines only three countries and the samples drawn were deliberately not randomised as there was a desire to select firms that had a strong innovation focus. Larger numbers of cases, drawn from other countries, should be gathered that will allow better international comparisons to be made. The discriminant analysis models were not strong predictors of these relationships and future research should also undertake additional quantitative analysis of the innovation diagnostic survey data to validate scales and assess the validity of the relationships found so far. Nevertheless, despite these limitations the study offers a window into the innovation practices of small firms and points to some benchmarks for superior management practice, enhanced policy support and future academic research.

\section{References}

ABS (2005) Innovation in Australian Business, Canberra, Australian Bureau of Statistics Cat No. 8158.0 AGPS.

Adams, R., Bessant, J. and Phelps, R. (2006) 'Innovation management measurement: a review', International Journal of Management Reviews, Vol. 8, No. 1, pp.21-47.

Akgun, A.E., Lynn, G.S. and Byrne, J.C. (2004) 'Taking the guess work out of new product development: how successful high-tech companies get that way', Journal of Business Strategy Vol. 25, No. 4, pp.41-46.

Autio, E. and Lumme, A. (1998) 'Does the innovator role affect the perceived potential for growth?: analysis of four types of new, technology-based firms', Technology Analysis and Strategic Management, Vol. 10, No. 1, pp.41-45. 
Birley, S., and Westhead, P. (1993) 'A comparison of new businesses established by 'novice' and 'habitual' founders in Great Britain', International Small Business Journal, Vol. 12, No. 10, pp.38-60.

Boag, D.A. and Rinholm, B.L. (1989) 'New product management practices of small high technology firms', Journal of Product Innovation Management, Vol. 6, No. 2, pp.109-122.

Cooper, R.G., Edgett, S.J. and Kleinschmidt, E.J. (2004a) 'Benchmarking best NPD practices: I', Research Technology Management, Vol. 47, No. 1, pp.31-43.

Cooper, R.G., Edgett, S.J. and Kleinschmidt, E.J. (2004b) 'Benchmarking best NPD practices: II', Research Technology Management, Vol. 47, No. 3, pp.50-59.

Cooper, R.G., Edgett, S.J. and Kleinschmidt, E.J. (2004c) 'Benchmarking best NPD practices: III', Research Technology Management, Vol. 47, No. 3, pp.43-55.

Coopey, J., Keegan, O. and Emler, N. (1997) 'Managers' innovations as 'sense-making', British Journal of Management, Vol. 8, No. 4, pp.301-315.

Cronbach, L.J. (1951) 'Coefficient alpha and the internal structure of tests', Psychometrica, Vol. 16, No. 3, pp.297-334.

DCITA (2004) Backing Australia's Ability: Building our Future Through Science and Innovation, Canberra, Department of Communications, Information, Technology and the Arts, Commonwealth of Australia.

Dernis, H. and Khan, M. (2004) 'Triadic patent families methodology', OECD Science and Technology Working Papers, 2004/2 (OECD Publishing).

Ferris, W.D. (2001) 'Australia chooses: venture capital and a future Australia', Australian Journal of Management, Special Issue, Vol. 26, pp.45-64.

Garrett-Jones, S. (2004) 'From citadels to clusters: the evolution of regional innovation policies in Australia', R\&D Management, Vol. 34, No. 1, pp.3-16.

Gibb, A.A. (2000) 'SME policy, academic research and the growth of ignorance, mythical concepts, myths, assumptions, rituals and confusions', International Small Business Journal, Vol. 18, No. 3, pp.13-35.

Grupp, H. and Maital, S. (2001) Managing New Product Development and Innovation: A Microeconomic Toolbox, Edward Elgar, Cheltenham UK, Northampton USA.

Huang, X., Soutar, G.N. and Brown, A. (2002) 'New product development processes in small to medium-sized enterprises: some Australian evidence', Journal of Small Business Management, Vol. 40, No. 1, pp.27-42.

Kemp, R.G.M., Folkeringa, M., de Jong, J.P.J. and Wubben, E.F.M. (2003) Innovation and Firm Performance, Zoetermeer, Netherlands, EIM Research Report H200207 SCALES Scientific Analysis of Entrepreneurship and SMEs.

Kerin, J. (2006) 'Why no science policy for Australia?', Australasian Science Vol. 27, No. 1, pp. $43-45$.

Khan, A.M. and Manopichetwattana, V. (1989) 'Innovative and non-innovative small firms: types and characteristics', Management Science, Vol. 35, No. 5, pp.597-606.

Kickul, J. and Gundry, L.K. (2002) 'Prospecting for strategic advantage: the proactive entrepreneurial personality and small firm innovation', Journal of Small Business Management, Vol. 40, No. 2, pp.85-97.

Klomp, L. and van Leeuween, G. (1999) The Importance of Innovation for Firm Performance, Statistics Netherlands, Netherlands.

Lee, Y. and O'Connor, G.C. (2003) 'The impact of communication strategy on launching new products: the moderating role of product innovativeness', Journal of Product Innovation Management, Vol. 20, No. 1, pp.4-21.

Marsh, S.P. and Pannell, D. (2000) 'Agricultural extension policy in Australia: the good, the bad and the misguided', The Australian Journal of Agricultural and Resource Economics, Vol. 44, No. 4, pp.605-627. 
Mattes, E., Stacey, M.C. and Marinova, D. (2006) 'Predicting commercial success for Australian medical inventions patented in the US: a cross sectional survey of Australian inventors', Medical Journal of Australia, Vol. 184, No. 1, pp.33-38.

Mazzarol, T. and Reboud, S. (2006) 'The strategic decision making of entrepreneurs within small high innovator firms', International Entrepreneurship and Management Journal, Vol. 2, No. 2, pp.261-280.

Mazzarol, T. and Reboud, S. (2005) 'Customers as predictors of rent returns to innovation in small firms: an exploratory study', International Journal of Entrepreneurship and Innovation Management, Vol. 5, Nos. 5/6, pp.483-494.

McDougall, P., Covin, J.G., Robinson, R.B. and Herron, L. (1994) 'The effects of industry growth and strategic breadth on new venture performance and strategy content', Strategic Management Journal, Vol. 15, No. 7, pp.537-554.

MEDEF (2002) 'Encourager l'innovation dans les PME françaises', GPA Entrepreneur et GPA Recherche et Innovation, 9 Décembre 2002.

MEFE (2006) Ministere de L'Economie des Finances et de L'Emploi, www.industrie.gouv.fr/observat/bilans/bord/cpci2006/2d.pdf.

Miles, R.E. and Snow, C.C. (1978) Organizational Strategy, Structure and Process, McGraw-Hill, New York.

Miles, R.E., Snow, C.C., Meyer, A.D. and Coleman, H.J. (1978) 'Organisational strategy structure and process', Academy of Management Review, Vol. 3, No. 3, pp.546-562.

Miller, W. (2001) 'Innovation for business growth', Research Technology Management, September-October, Vol. 66, pp.26-41.

Molina-Azorin, J.F. (2007) 'Mixed methods in strategy research: applications and implications in the resource-based view', Research Methodology in Strategy and Management, Vol. 4, No. 1, pp.37-73.

Molyneux, A. (2000) 'Innovation: the view from the summit', Australian CPA, Vol. 70, No. 3, pp.24-25.

North, D. and Smallbone, D. (2000) 'The innovativeness and growth of rural SMEs during the 1990s', Regional Studies, Vol. 34, No. 2, pp.145-157.

OECD (2001) Oslo Manual: The Measurement of Scientific and Technological Activities: Proposed Guidelines for Collecting and Interpreting Technological Innovation Data, Organisation of Economic Co-operation and Development, European Union, Eurostat.

OECD (2004) 'SME statistics: towards a more systematic statistical measurement of SME behaviour', Promoting Entrepreneurship and Innovative SMEs in a Global Economy, Organisation for Economic Co-operation and Development, Istanbul, Turkey, 3-5 June, Paris.

OECD (2007) OECD Statistics online at http://stats.oecd.org.

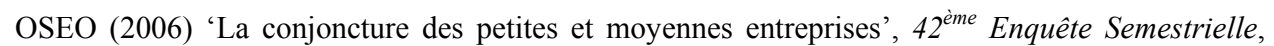
janvier 2006 Oséo Services.

Ozer, M. (2004) 'Managing the selection process for new product ideas', Research Technology Management, Vol. 47, No. 4, pp.10-11.

Pavia, T.M. (1990) 'Product growth strategies in young high-technology firms', Journal of Product Innovation Management, Vol. 7, No. 4, pp.297-309.

Reboud, S. and Mazzarol, T.W. (2006) 'Evaluation du risque lie a une innovation pour les PME: proposition d'un outil', Revue Internationale P.M.E., Vol. 19, No. 2, pp.133-161.

Roach, T. (2000) 'Saving Aussie science from third world status', Australasian Science, Vol. 27, No. 5, p.42.

Salomo, S., Weise, J. and Gemunden, H.G. (2007) 'NPD planning activities and innovation performance: the mediating role of process management and the moderating effect of product innovativeness', Journal of Product Innovation Management, Vol. 24, No. 4, pp.285-302. 
Sandberg, B. (2002) 'Creating the market for disruptive innovation: market pro-activeness at the launch stage', Journal of Targeting, Measurement and Analysis for Marketing, Vol. 11, No. 2, pp.184-197.

Santi, M., Reboud, Sophie., Gasiglia, Hervé, et. and Sabouret, Alexandre., (2003) Modèle de Valorisation et de Protection Intellectuelle des Innovations des PEI, July, HEC/INPI, p.63.

SESSI (2006) Tableau de bord de l'Innovation, 16ème édition, Novembre 2006.

Stringer, R. (2000) 'How to manage radical innovation', California Management Review, Vol. 42, No. 4, pp.70-88.

Vazquez, R., Santos, M.L. and Alvarez, L.I. (2001) 'Market orientation, innovation and competitive strategies in industrial firms', Journal of Strategic Marketing, Vol. 9, No. 1, pp.69-90.

Vermeulen, P. (2005) 'Uncovering barriers to complex incremental product innovation in small and medium-sized financial services firms', Journal of Small Business Management, Vol. 43, No. 4, pp.432-452.

Weinzimmer, L.G. (1997) 'Top management team correlates of organizational growth in a small business context: a comparative study', Journal of Small Business Management, Vol. 35, No. 3, pp.1-9.

Wilks, S.S. and Thompson, C.M. (1937) 'The sampling distribution of the criterion Lambda when the hypothesis tested in not true', Biometrika, Vol. 29, No. 1/2, pp.124-132.

Wood, F. (1992) 'The commercialisation of University research in Australia: issues and problems', Comparative Education, Vol. 28, No. 3, pp.293-313.

Yencken, J. and Gillin, M. (2006) 'A longitudinal comparative study of university research commercialisation performance: Australia, UK and USA', Innovation, Vol. 8, No. 3, pp.214-227.

\section{Appendix A}

Innovation diagnostic items

Market index (Alpha $=0.799)$

Have you fully researched the benefits as perceived by the customer for this innovation?

Have you fully explored the most appropriate pricing strategy?

Have you researched how easily customers will understand it?

Have you researched how easy it will be for customers to test or trial it prior to adoption?

Have you researched how easy it will be for customers to do post adoption evaluations?

Have you fully explored how compatible it is with customers' existing technologies/systems?

Have you fully examined customer perceptions of risk and cost?

Have you fully explored the opportunities it offers customers?

Have you previously collaborated with customers over innovations?

Have you researched if there is already a customer ready to adopt this innovation? 


\section{Innovation diagnostic items (continued)}

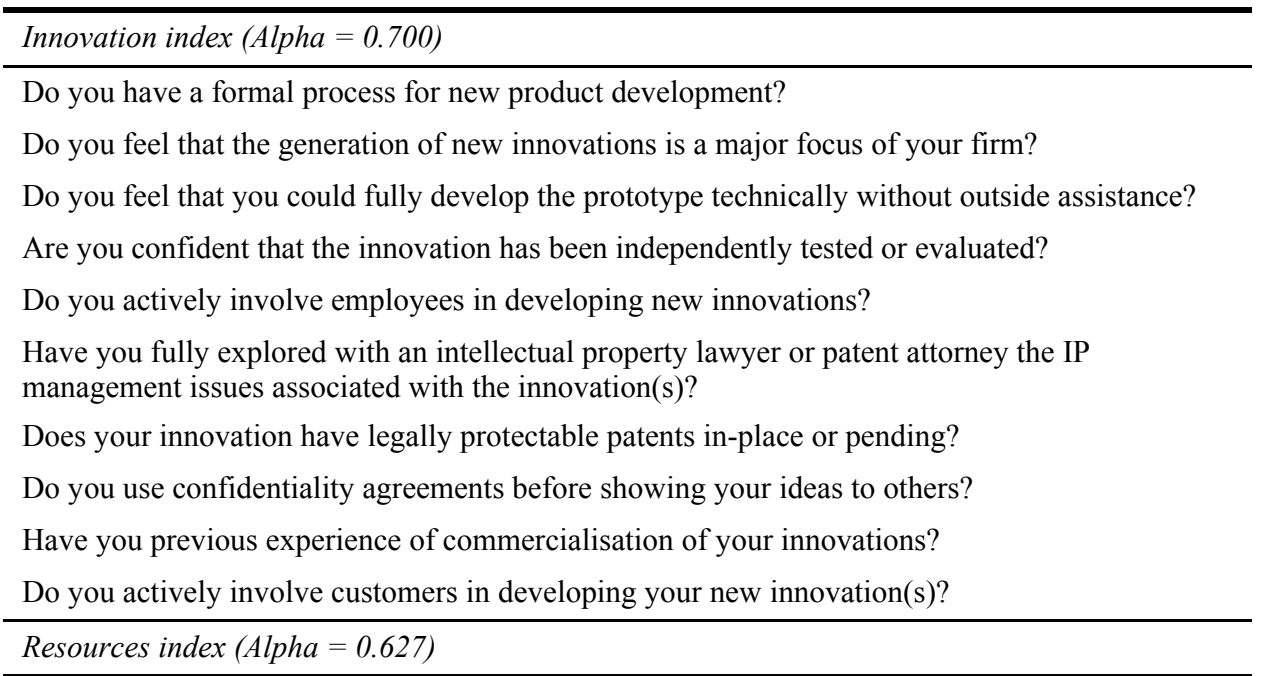

Do you already have the technological resources to create a prototype?

Do you have the competencies to fully commercialise the innovation alone?

Do you have an experienced project management team to work on the idea?

Do you know how to find external expert assistance if required?

Are staffing resources adequate for the future development of the idea?

Are physical resources adequate for the future development of the idea?

Are financial resources adequate for the future development of the idea?

Have you fully explored government assistance programs designed to help small firms with commercialisation?

Have you identified sources of venture capital financing for the innovation?

Do you have a management board to provide guidance and advice?

Strategy index $($ Alpha $=0.767)$

Do you have a formal, written business plan for your innovation?

Have you fully assessed the bargaining power of your customers?

Have you fully assessed the bargaining power of your suppliers?

Have you fully assessed the threat of alternative technologies to yours?

Have you fully assessed the reaction of competitors to your innovation?

Have you fully assessed the reaction of complementary partners able to assist you?

Have you considered existing or anticipated government regulations?

Have you secured all necessary compliances and authorisations?

Have you undertaken a risk assessment in the light of potential threats?

Have you completed a comprehensive financial model? 